\title{
IMPLEMENTASI PENGELOLAAN SAMPAH RUMAH TANGGA MELALUI PELATIHAN PEMBUATAN PUPUK KOMPOS METODE TAKAKURA PADA MASYARAKAT DI TANGERANG SELATAN
}

\author{
${ }^{1)}$ Izza Hananingtyas*, ${ }^{2)}$ Mellyania Kencana Dewi, ${ }^{3)}$ Nurul Fadhillah Kundari, \\ ${ }^{4}$ Mala Zelika Yahya Putri, ${ }^{5}$ Qonita Nur Salamah, ${ }^{6}$ Putri Mulia Hayati Sibarani, \\ ${ }^{7}$ Eva Safitri, ${ }^{8}$ Fidah Syadidurahmah \\ 1,2,3,4,5,6,7,8) Program Studi Kesehatan Masyarakat, Fakultas Ilmu Kesehatan Universitas \\ Islam Negeri Syarif Hidayatullah Jakarta \\ Alamat: Jl. Kertamukti No.5, Pisangan, Ciputat, Tangerang Selatan \\ Email: izza.hananingtyas@uinjkt.ac.id
}

\begin{abstract}
ABSTRAK
Berdasarkan data dari Dinas Lingkungan Hidup Tangerang Selatan pada tahun 2018, Tangerang Selatan Tangerang selatan menghasilkan sampah hingga 1.000 ton per hari. Jumlah sampah tertinggi yaitu 43,39\% sampah organik dari dapur rumah tangga. Kegiatan pengabdian masyarakat yang dilakukan oleh tim Kesehatan Masyarakat UIN Syarif Hidayatullah bertujuan untuk meningkatkan pengetahuan, keterampilan, kesadaran untuk menerapkan pengelolaan limbah rumah tangga dengan Pelatihan Pupuk Kompos Takakura di Tangerang Selatan. Kegiatan ini dilakukan kepada Majelis Ta'lim dan kader kesehatan RW 04 Lengkong Gudang. Hasil dari kegiatan ini menunjukkan 78,6\% peserta pelatihan melakukan pengolahan sampah organik di rumah mereka dan $71,4 \%$ peserta pelatihan merekomendasikan metode Takakura kepada orang-orang di sekitar, 67,9\% masyarakat yang berpartisipasi merespons positif pengelolaan limbah rumah tangga dengan metode Takakura. Kegiatan ini diharapkan mampu mendorong masyarakat untuk menerapkan pengelolaan sampah rumah tangga. Dengan demikian, ini akan mengurangi limbah rumah tangga dan risiko dampak lingkungan, sehingga secara tidak langsung juga akan meminimalkan dampak kesehatan.
\end{abstract}

Kata kunci: sampah organik, Takakura, pengelolaan sampah, pengabdian masyarakat

\section{ABSTRACT}

Based on data from the South Tangerang Environment Office in 2018, South Tangerang produces up to 1.000 tons of waste per day. The highest amount of waste is $43.39 \%$ organic waste from household kitchens. Community service activities undertaken by the Public Health team of UIN Syarif Hidayatullah aimed to to increase the knowledge, skills, awareness to implement household waste management by Training Takakura Compost Fertilizer in South Tangerang. This activity was carried out for the religious study group and health cadres of $R W 04$ Lengkong Gudang. The results of this activity showed $78.6 \%$ of trainees doing organic waste processing in their homes and $71.4 \%$ of trainees recommending the Takakura method to people around, $67.9 \%$ participants responded positively to manage household waste by the Takakura method. It was expected to be able to encourage the community to implement household waste management. Thus, it will reduce household waste and the risk of environment effect, so it also will indidirectly minimize health effect.

Keyword: organik waste, Takakura, waste management, community service 
AS-SYIFA: Jurnal Pengabdian dan Pemberdayaan Kesehatan Masyarakat

\section{PENDAHULUAN}

Undang-undang Republik Indonesia Nomor 18 Tahun 2008 tentang Pengelolaan Sampah, menyebutkan bahwa sampah adalah sisa kegiatan sehari-hari manusia dan/atau proses alam yang berbentuk padat. Setiap kegiatan manusia pasti menghasilkan sampah. Paradigma baru dalam pengelolaan sampah menerapkan pengelolaan sampah secara holistik dari hulu sampai hilir. Peraturan Pemerintah Republik Indonesia Nomor 81 Tahun 2012 Tentang Pengelolaan Sampah Rumah Tangga Dan Sampah Sejenis Sampah Rumah Tangga menjelaskan bahwa sampah rumah tangga adalah sampah yang berasal dari kegiatan sehari-hari dalam rumah tangga yang tidak termasuk tinja dan sampah spesifik. Pengelolaan sampah adalah kegiatan yang sistematis, menyeluruh, dan berkesinambungan yang meliputi pengurangan dan penanganan sampah. Program pengelolaan sampah merupakan program yang dirancang agar dapat mengurangi efek lingkungan dan kesehatan yang diakibatkan adanya penumpukan sampah di lingkungan masyarakat.

Kota Tangerang Selatan setiap harinya menghasilkan jumlah sampah dengan katagori tinggi dengan jumlah 880 ton/hari di tahun 2017 dan tahun 2018 mencapai 1.000 ton per hari , dengan jumlah timbulan sampah tertinggi yaitu sampah organik 43,39\%, sampah anorganik 26,52\%, sampah B3 14,45\%, dan sampah lainnya 15,64\% (DLH Kota Tangerang Selatan, 2018). Tentu hal ini menjadi permasalahan yang pelik yang sedang dihadapi Kota Tangerang Selatan. Maka dari itu perlu strategi bagaimana caranya agar sampah organik, dapat diolah untuk meminimalisir jumlah timbulan sampah yang diangkut ke Tempat Pembuangan Akhir, sesuai dengan kebijakan pengelolaan sampah di wilayah perkotaan dalam UU No.18 Tahun 2008 tentang Pengelolaan Sampah.

Berdasarkan hasil dari observasi awal di Tahun 2020 wilayah Tangerang Selatan, diperoleh hasil bahwa 50\% melakukan pengelolaan sampah dengan cara dibakar. Hal ini menjadi perhatian khusus karena kurangnya pengelolaan sampah yang baik dan aman untuk lingkungan dan kesehatan. Berdasarkan penelitian Asriati (2012), menyatakan bahwa orang yang tinggal dekat dengan sumber pembakaran tertentu dan konsentrasi kandungan berbahaya dalam asapnya lebih tinggi terkena penyakit pernapasan khususnya seperti, Pneumonia, dan ISPA. Pembakaran sampah, dimungkinkan akan menimbulkan asap mengandung partikel yang akan masuk ke dalam saluran pernafasan sehingga dapat mempengaruhi kejadian ISPA.

Dari observasi tersebut, maka diperlukan pemberdayaan masyarakat yang dapat menggerakkan masyarakat Tangerang Selatan untuk dapat mengelola sampah rumah tangganya agar meminimalisir timbulan sampah dan kegiatan pembakaran di lingkungan tempat tinggalnya intuk mengurangi efek lingkungan dan kesehatan dari akibat pembakaran sampah dan menumpuknya sampah di lingkungan tempat tinggal. Mahasiswa Program Studi Kesehatan Masyarakat FIKes UIN Syarif Hidayatullah Jakarta melaksanakan pengabdian masyarakat melalui pelatihan Pembuatan Pupuk Kompos dengan metode Takakura pada masyarakat di lingkungan Kelurahan Lengkong Gudang Kota Tangerang Selatan sebagai wilayah percontohan untuk pengelolaan sampah organik di wilayah Tangerang selatan guna meminimalisir jumlah timbulan sampah dan praktik pengelolaan sampah yang buruk dengan cara di bakar. Berdasarkan penelitian yang dilakukan Kurniawan (2013 diketahui bahwa Kota Surabaya telah berhasil mengurangi timbulan sampah di TPA Benowo sebanyak 30\% dari hasil pengelolaan sampah melalui kompostng dengan metode Takakura dan telah menghasilkan lebih dari 40.000 takakura dan sekitar 900 kompos yang didistribusikan secara bebas ke komunitas lokal, dengan 400 fasilitator lingkungan kota dan 28.000 kader lingkungan terlibat. 
Kegiatan pengabdian masyarakat ini bertujuan agar setelah masyarakat mengetahui cara pengelolaan sampah melalui pengolahan sampah menjadi pupuk kompos dengan metode Takakura dapat membiasakan dalam kehidupan sehari - hari, maka sampah tersebut dapat diolah berdasarkan jenisnya melalui metode composting Takakura. Metode ini dikembangkan oleh ahli dari Jepang Mr. Koji Takakura di Surabaya. Metode ini diterapkan dengan upaya meningkatkan kemampuan masyarakat/rumah tangga dalam mengelola sampah organik yang berpotensi mencemari air, tanah, ataupun udara melalui media keranjang sakti dan proses aerob.

Pelatihan pembuatan pupuk kompos dengan metode takakura bertujuan untuk melatih masyarakat agar mampu mengolah sampah organiknya.. Masyarakat akan merancang sendiri media pembuatan pupuk komposnya setelah dibekali tata cara pembuatan. Dalam pelaksanaan pembuatan media, masyarakat dibimbing oleh pemateri dan fasilitator dari tim pelatih. Media pembuatan kompos yang telah dibuat oleh peserta pelatihan akan dibawa pulang masing - masing sehingga dapat diaplikasikan dirumah masing - masing. Hasil yang diharapkan pada pelatihan ini adalah masyarakat melakukan pengolahan sampah organik menjadi pupuk kompos dengan metode takakura di rumah masing - masing. Sehingga pengolahan sampah dengan pembakaran di lahan dapat berkurang, pengolahan sampah yang dilakukan selanjutnya yaitu pembuatan pupuk kompos dengan metode Takakura.

\section{METODE}

Kegiatan Pengabdian masyarakat ini terbagi menjadi 3 tahapan kegiatan. Tahapan pertama adalah tahapan persiapan yaitu, tim pengabdian masyarakat melakukan rapid survey untuk menentukan permasalahan, diketahui ISPA menduduki peringkat pertama angka kesakitan di Wilayah Kerja Puskesmas Serpong 1 dengan akar masalahnya pada kegiatan Pembakaran Sampah 50\% di wilayah Lengkong Gudang. Setelah itu tim pengabdian masyarakat menentukan sasaran intervensi pada Ibu-Ibu Majelis Ta'lim dan Ibu-Ibu Kader di RW 04 Lengkong Gudang. Tahapan kedua adalah tahapan kegiatan inti yang meliputi pelatihan dan praktik pembuatan pupuk kompos dengan metode Takakura. Tahapan ketiga adalah tahapan evaluasi dan monitoring dari implementasi pengelolaan sampah melalui pembuatan pupuk kompos dengan metode Takakura di Lengkong Gudang Kota Tangerang Selatan. Melalui kegiatan ini diharapkan dapat diketahui seberapa efektifkan pelatihan pebuatan pupuk kompos ini untuk mengimplementasikan pengelolaan sampah guna mengurangi volume timbulan sampah rumah tangga dan mengurangi kegiatan pembakaran sampah di lingkungan tempat tinggal yang dapat berimplikasi pada tingginya angka kesakitan ISPA di wilayah Kerja Puskesmas Serpong I.

Pelaksanaan kegiatan pengabdian masyarakat ini dilakukan dengan metode pelatihan pembuatan pupuk kompos metode Takakura pada Ibu-Ibu Majelis Ta'lim dan Ibu-Ibu Kader di RW 04 Lengkong Gudang. Media yang digunakan saat pelatihan yaitu dengan audio visual dan media flyer untuk dapat dibawa pulang sebagai panduan praktik di rumah. Setelah para peserta pelatihan memahami cara pembuatan pupuk kompos dengan metode Takakura melalui penjelasan Tutor/Pelatih, mereka dibagikan media pembuatan pupuk kompos dan keranjang Takakura untuk dipraktikan bersama dan membawa pulang keranjang Takakura serta bahan media pembuatan pupuk kompos ke rumah untuk dipraktikkan di rumah dan disalurkan ilmunya kepada masyarakat di lingkungan tempat tinggal mereka. Ibu-ibu peserta pelatihan dilakukan evaluasi melalui kuesioner setelah 1 minggu berjalan dan survey pra kegiatan telah dilakukan sebelum pelatihan berlangsung. Sehingga dari hasil pra dan post kegiatan dapat diketahui efektifitas implementasi 
ISSN (online): 2722-2055 https://jurnal.umj.ac.id/index.php/ASSYIFA
AS-SYIFA: Jurnal Pengabdian dan Pemberdayaan Kesehatan Masyarakat

pengelolaan sampah melalui pembuatan pupuk kompos metode Takukra.

\section{HASIL DAN PEMBAHASAN}

Kegiatan Pengabdian Masyarakat ini bertujuan untuk meningkatkan kesadaran masyarakat Tangerang Selatan untuk mengelola sampah rumah tangganya melalui pembuatan pupuk kompos metode Takakura untuk mengurangi timbulan sampahnya dan mengurangi kegiatan pembakaran di lingkungan tempat tinggal. Kegiatan pengabdian masyarakat ini dilakukan berdasarkan analisa situasi kesehatan masyarakat di wilayah kerja puskesmas Serpong 1 Kota Tangerang Selatan melalui studi literatur dari sumber informasi data puskesmas dan survey cepat kepada 229 responden warga Kecamatan Serpong Kota Tangerang Selatan.

Berdasarkan data survey cepat pada 229 responden di wilayah Kelurahan Lengkong Gudang Kota Tangerang Selatan diketahui bahwa, frekuensi penyakit ISPA menempati peringkat tertinggi dengan frekuensi sebesar 43,08\%. Hal ini sejalan dengan laporan bulanan Puskesmas Serpong 1, selama 10 bulan terakhir, angka kesakitan penyakit ISPA selalu menempati pringkat tertinggi dengan frekuensi kasus sebesar 58\%. Infeksi Saluran Pernapasan Akut (ISPA) adalah penyakit infeksi akut yang menyerang salah satu bagian atau lebih dari saluran napas mulai hidung sampai alveoli termasuk asinus, rongga telinga tengah, pleura (Kemenkes, 2011).

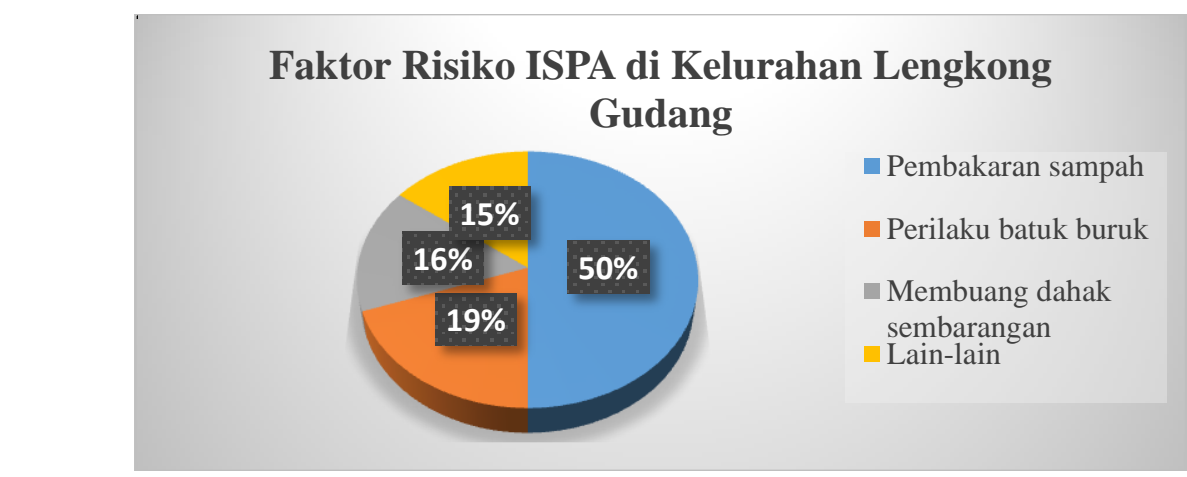

Gambar 1. Faktor Risiko ISPA di Kelurahan Lengkong Gudang Kota Tangerang Selatan

Berdasarkan gambar 1, diketahui dari data primer yang didapat melalui rapid survey, didapatkan akar masalah yang menjadi faktor risiko penyakit ISPA di kelurahan tersebut, yaitu terdapat 50\% responden melakukan pengelolaan sampah dengan cara dibakar. Melalui pembakaran sampah, dimungkinkan akan menimbulkan asap yang dapat mempengaruhi kejadian ISPA. Diketahui factor lainnya yaitu perilaku batuk yang buruk 19,6\%. Selain itu, terdapat $15,7 \%$ yang memiliki perilaku membuang dahak sembarangan. Dan $14,7 \%$ faktor yang lainnya terkait perilaku hidup bersih dan sehat (PHBS). Berdasarkan hasil tersebut diketahui faktor paling besar yang menjadi faktor risiko ISPA adalah perilaku pembakaran sampah sembarangan. Sehingga tim pengabdian masyarakat memilih intervensi dalam pengelolaan sampah rumah tangga di wilayah Kelurahan Lengkong Gudang Kota Tangerang Selatan. Gambar 2 di bawah ini merupakan foto hasil kegiatan pengabdian masyarakat kepada ibu - ibu majelis ta'lim dan ibu kader RW 04 Kelurahan Lengkong Gudang Kota Tangerang Selatan. 

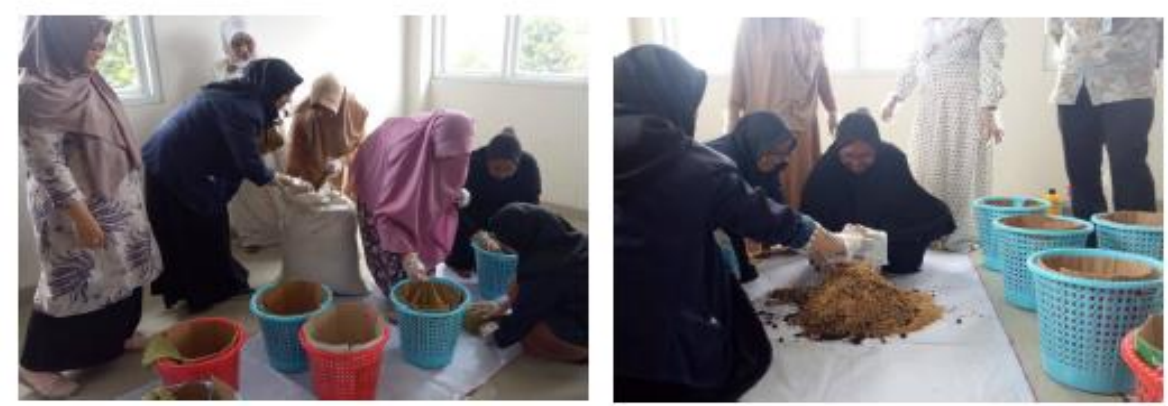

Gambar 2. Kegiatan Pelatihan Pembuatan Kompos dengan Metode Takakura

Sasaran kegiatan pengabdian masyarakat ini adalah ibu-ibu majelis ta'lim dan kader kesehatan wilayah RW 04, dengan pertimbangan wilayah ini yang memiliki persentase tetinggi pada pengelolaan sampah yang dibakar di lingkungan tempat tinggal. Pelatihan pembuatan pupuk kompos dengan metode Takakura ini, dapat meningkatkan kesadaran masyarakat untuk mengimplementasikan pengelolaan sampah rumah tangga yang termasuk dalam golongan organik untuk mengurangi timbulan sampah dan mengurangi kegiatan pembakaran sampah di sekitar tempat tinggal mereka.

Berdasarkan hasil survey pra kegiatan, sebanyak 50\% masyarakat diketahui tidak mengelola sampahnya dengan baik, justru membakar sampahnya di lingkungan tempat tinggal mereka. Pelaksanaan kegiatan pelatihan pembuatan pupuk kompos dengan metode takakura sangat memberikan motivasi kepada ibu-ibu rumah tangga yang mengikuti pelatihan, dan dapat di implementasikan dengan baik di kehidupan sehari-hari. Hal ini dapat dilihat dari hasil survey pasca kegiatan pelatihan yang diambil pada 7 hari setelah pelaksanaan pelatihan melalui kuesioner kepada masing - masing peserta pelatihan. Hasil dari survey implementasi masyarakat untuk melaksanakan pengolahan sampah menjadi kompos melalui metode Takura dapat dilihat seperti pada gambar 2 berikut:



Gambar 2. Survey Implementasi Masyarakat Pasca Pelatihan

Berdasarkan Gambar 2 di atas, diketahui survey evaluasi yang dilakukan pasca pelatihan diketahui bahwa dari 28 responden sebanyak 78,6\% melakukan pengolahan sampah organik, serta $21,4 \%$ tidak pernah melakukan pengolahan sampah organik. Pada perilaku penerapan pembuaatan pupuk kompos dengan metode takakura, sebanyak $67,9 \%$ responden mengolah sampah organik dengan metode takakura. Adapun dalam merekomendasikan metode takakura terhadap orang disekitar, sebanyak $71,4 \%$ merekomendasikan metode takakura. Hal ini disadari oleh responden bahwa perubahan 
yang mereka lakukan karena efektifnya kegiatan pelatihan pengolahan sampah menjadi pupuk kompos melalui metode Takakura. Dari hasil tersebut terlihat bahwa dengan adanya pelatihan pembuatan kompos metode Takakura ini meningkatkan kesadaran masyarakat sebesar 78,6\% untuk dapat menerapkan pengelolaan sampah dengan baik melalui pengomposan. Sehingga banyak dari responden yang akhirnya menularkan keahlian barunya kepada orang lain sebesar $71,40 \%$ untuk ikut serta mengolah sampah organik rumah tangganya menjadi pupuk kompos. Dan dari hasil rekomendasi dari para peserta, sebanyak $67,90 \%$ masyarakat yang menerima dengan positif untuk merubah perilaku mereka dalam mengolah sampah organik rumah tangganya untuk menjadi pupuk kompos sehingga dapat mengurangi kegiatan pembakaran dan timbulan sampah rumah tangga pada masyarakat RW 04 Kelurahan Lengkong Gudang, Kota Tangerang Selatan.

Keberhasilan pelatihan pembuatan kompos metode Takakura pada masyarakat, dapat dilihat dari faktor-faktor yang mempengaruhi keberhasilan suatu metode pemberdayaan masyarakatnya. Pada akhir sesi pelatihan, tim pengabdian masyarakat mebuat angket evaluasi dari kegiatan, yang dapat dilihat pada gambar 3 sebagai berikut:

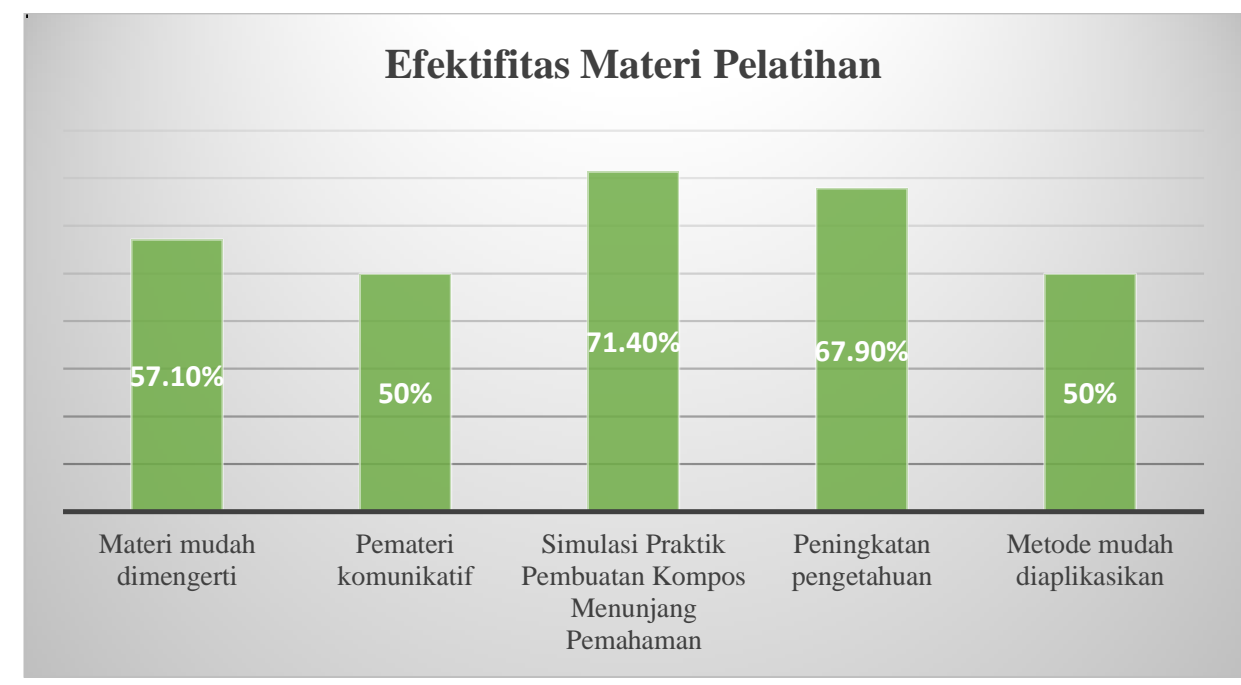

Gambar 3. Efektifitas Materi Pelatihan

Berdasarkan gambar 3 di atas, diketahui bahwa sebanyak 57,1\% responden setuju bahwa materi yang disampaikan mudah untuk dimengerti. Selain itu, sebanyak 50\% responden juga mengungkapkan setuju bahwa pemateri menyampaikan pesan dengan baik. Pada indicator pelaksanaan simulasi pembuatan pupuk, sebanyak $71,4 \%$ responden setuju bahwa simulasi dilakuakn dengan jelas. Setelah mengikuti pelatihan, sebanyak 67,9\% merasa setuju bahwa terjadinya peningkatan pengetahuan terkait pembuatan pupuk kompos dengan memanfaatkan sampah dapur. Dan sebanyak 50\% responden setuju bahwa metode takakura ini mudah diaplikasikan di rumah.

Pengelolaan sampah dengan metode sedrhana seperti metode pengomposan Takakura di lingkungan tempat tinggal perlu disikapi untuk mengurangi timbulan sampah serta pengelolaan sampah yang buruk dengan cara dibakar. Pelatihan pembuatan pupuk kompos metode Takakura dalam kegiatan pengabdian ini bertujuan untuk: (1) Meningkatkan pengetahuan masyarakat Desa Kedung Sumur tentang pengelolaan sampah rumah tangga. (2) Memberdayakan masyarakat dalam pemilahan sampah rumah tangga (Tamyis,dkk , 2018). Hal sejalan dengan penelitian Wahyuni (2019), diketahui bahwa pemanfaatan sampah organik rumah tangga menjadi pupuk kompos dapat mengoptimalkan 
sampah organik rumah karena sangat mudah ditemukan disetiap tempat. Dengan adanya pupuk kompos organik ini dapat dijadikan alternatif bagi masyarakat sekitar yang sebagian besar berkerja sebagai pekebun dan petani agar dapat beralih dari pupuk berbahan kimia ke pupuk kompos organik.

Dari hasil data di atas, dapat dilihat bahwa keberhasilan pengimplementasian masyarakat dapat di lihat indikator tertinggi yaitu pada aspek melakukan pengolahan sampah dengan metode Takakura sebesar 78,60\%. Hal ini dapat didukung karena adanya indikator simulasi praktik pada saat pelatihan yaitu sebesar 71,40\%. Sehingga masyarakat memahami dan dapat mempraktikan sendiri di rumah. Selain itu berdasarkan evaluasi kegiatan pelatihan, masyarakat merasakan aspek materi yang mudah dimengerti dan pemateri yang komunikatif, sehingga dapat meningkatkan $67,90 \%$ pengetahuan peserta pelatihan tentang metode pengomposan Takakura, selain itu 50\% peserta pelatihan merasakan aspek metode yang mudah diaplikasikan. Keunggulan metode takakura untuk pelatihan pembuatan pupuk kompos yaitu masyarakat dapat memahami dengan mudah, aplikatif karena dapat dilakukan oleh siapapun, lebih higienis, dan dapat dilakukan dimana saja.

Menurut Pranata,dkk (2011) pada dasarnya terdapat 7 prinsip yang harus diperhatikan dalam melakukan pemberdayaan antara lain: prinsip menumbuh kembangkan potensi masyarakat, meningkatkan kontribusi masyarakat, mengembangkan budaya gotong royong, bekerja bersama masyarakat, pendidikan berbasis masyarakat, kemitraan dan desentralisasi. Jika di lihat dari tujuh prinsip pemberdayaan masyarakat di atas, tim pengabdian masyarakat melaksanakan pengabidanmasyarakat dengan berdasarkan pada prinsip pemberdayaan masyarakat. Hal imi dapat telah terlihat dari pengimplementasian 7 prinsip pemberdayaan masyarakat yaitu aspek potensi yang dapat dikembangkan oleh masyarakat yaitu banyak ibu rumahtangga yang menghasilkan sampah organik, dimana hal ini menjadi potensi untuk dilakukannya pemberdayaan pembuatan kompos. Selanjutnya aspek kontribusi masyarakat,juga terlihat dari tingginya peserta pelatihan yang merekomendasikan kepada orang - orang terdekatnya untuk mengimplementasikan pengolahan sampah secara metode Takakura yaitu sebesar 71,40\%. Hal tersebut juga termasuk dalam aspek budaya gotong royong dan bekerja sama pada kegiatan pengabdian masyarakat. Karena ketika merekomendasikan mereka langsung mengajarkan secara praktik kepada orang-orang terdekatnya, sehingga terkandung aspek kerja sama dan gotong royong di dalamnya. Pada aspek Pendidikan berbasis masyarakat ini telah diterapkan pada peserta ketika mereka merekomendasikan kepada orang terdekatnya serta dapat meningkatkan persepsi positif pada masyarakat ubtuk ikut mengimplementasikan kegiatan ini dalam kegidupan sehari-hari sebesar $67,90 \%$.

Umanailo (2018) menyatakan bahwa pemberdayaan masyarakat merupakan suatu proses yang bertujuan untuk perubahan. Pemberdayaan masyarakat merupakan suatu upaya untuk memberikan kemampuan sekaligus kesempatan kepada masyarakat untuk ikut berperan aktif dalam pembangunan. Salah satu dampak positif pelaksanaan program pemberdayaan masyarakat, yaitu masyarakat mampu mengambil tanggungjawab terhadap pekerjaan mereka. Dari hal tersebut diharapkan dengan adanya pengabdian masyarakat berbasis pemberdayaan masyarakat dapat meningkatkan kemampuan dan tanggung jawab masyarakat terhadap kesehatan lingkungan melalui pengelolaan sampah rumah tangga dengan cara pembuatan kompos dengan metode Takakura. Dari hasil pengabdian masyarakat ini, dapat diketahui bahwa masyarakat mampu menerima pelatihan ini dengan baik dan mendukung masyarakat sekitar untuk mengimplementasikan praktik pengelolaan sampah rumah tangga melalui pembuatan kompos metode Takakura. Dengan adanya 
kegiatan pengabdian masyarakat melalui pelatihan ini memiliki nilai aspek penyajian materi yang mudah dimengerti, pelatih yang komunikatif, simulais praktik pembuatan kompos dan metode yng mudah dipahami, dapat meningkatkan pemahaman dan pengetahuan masyarakat terkait pengelolaan sampah dan pengolahan sampah melalui kegiatan composting limbah rumah tangga dengan metode Takakura.

\section{KESIMPULAN DAN SARAN}

Kegiatan pengabdian masyarakat melalui kegiatan "Pelatihan Pembuatan Pupuk Kompos dengan Metode Takakura" dapat melatih masyarakat agar mampu mengolah sampah organiknya. Hal ini dapat terlihat dari hasil $78,6 \%$ peserta pelatihan melakukan pengolahan sampah organik di rumahnya dan merekomendasikan metode takakura kepada orang disekitar sebanyak $71,4 \%$, serta mendapat respon positi dari masyarakat untuk melakukan pengelolaan sampah metode Takakura sebanyak 67,9\%. Kegiatan ini diharapkan menjadi pendorong masyarakat untuk dapat mengimplementasikan pengelolaan sampah rumah tangga melalui pembuatan pupuk kompos metode Takakura di lingkungan tempat tinggal, agar meminimalisir efek kesehatan dan lingkungan dari kegiatan pengelolaan sampah yang buruk dengan cara dibakar.

\section{UCAPAN TERIMA KASIH}

Tim penulis mengucapkan penghargaan dan terima kasih kepada pihak Kelurahan Lengkong Gudang, Ibu-ibu majelis ta'lim dan ibu kader kesehatan yang telah berpartisipasi aktif dalam kegiatan pengabdian masyarakat ini sehingga dapat berjalan lancar dan memberi manfaat kepada masyarakat untuk menjadi kader pelatihan pembuatan kompos metode Takakura selanjutnya. Terima kasih atas kerjasamanya dari pihak Puskesmas Serpong 1 yang telah membantu dalam proses literasi.

\section{DAFTAR PUSTAKA}

Asriati, M. Zamrud, and Dewi Febrianty Kalenggo. 2012. Analisis Faktor Risiko Kejadian Infeksi Saluran Pernapasan Akut Pada Anak Balita. Jurnal Kesehatan Masyarakat. Vol. 6 No. 1. Stikes Muhammadiyah Gembong.

Aryungga, S.D.E., et al . 2019. Pelatihan Pembuatan Kompos Menggunakan Metode Takakura Di SMP Luqman Al Hakim Ngawi. Indonesian Journal of Community Engagement (IJCE): LPPM STKIP Modern Ngawi Vol.1 No.1

Harlis et al . 2019. Pelatihan Pembuatan Kompos Organik metode Keranjang Takakura Sebagai Solusi Penanganan Sampah di Lingkungan Kost Mahasiswa. DEDIKASI : Jurnal Pengabdian Masyarakat Vol.1 No.1 Januari-Juni 2019

Kurniawan T.A., de Oliveira J.A.P. 2014. Technology Adaptation and Assimilation of Takakura for Promoting Environmental Protection in Surabaya (Indonesia) Through City Level Cooperation. In: Vazquez-Brust D., Sarkis J., Cordeiro J. (eds) Collaboration for Sustainability and Innovation: A Role For Sustainability Driven by the Global South. Greening of Industry Networks Studies, vol 3. Springer, Dordrecht

Peraturan Pemerintah Republik Indonesia Nomor 81 Tahun 2012 Tentang Pengelolaan Sampah Rumah Tangga Dan Sampah Sejenis Sampah Rumah Tangga

Pranata, S., Pratiwi, N.L., and Rahanto,S. 2011. Pemberdayaan Masyarakat di Bidang Kesehatan, gambaran peran kader posyandu dalam upaya penurunan angka kematian ibu dan bayi di Kota Manado dan Palangkaraya. Buletin Penelitian Sistem Kesehatan . Vol. 14 No. 2 April 2011: 174-182 
AS-SYIFA: Jurnal Pengabdian dan Pemberdayaan Kesehatan Masyarakat

Profil. Dinas Lingkungan Hidup. Kota Tangerang Selatan, 2018

Umanailo, M.Cjoirul Basrun. Integration of Community Empowerment Models [Pengintegrasian Model Pemberdayaan Masyarakat] (2018) Proceeding of Community Development Volume 2 (2018): 268-277; DOI: https://doi.org/10.30874/comdev.2018.319

Undang-undang Republik Indonesia Nomor 18 Tahun 2008 tentang Pengelolaan Sampah

Tamyis, M. 2018. Pelatihan Pengomposan Sampah Organik Dengan Sistem Takakura Pada Siswa Ma Darul Ulum Waru. Journal of Science and Social Development, Vol. 1 No. 1 Juni 2018 E-ISSN: 2477 - 6165

Wahyuni, S., et al . 2019. Pelatihan Pengolahan Sampah Organik Skala Rumah Tangga Dengan Metode Takakura Di Desa Gebugan. Indonesian Journal of Community Empowerment (IJCE) : Fakultas Ilmu Kesehatan, Universitas Ngudi Waluyo 
